\title{
Response of Herbicide-Resistant Palmer Amaranth (Amaranthus palmeri) Accessions to Drought Stress
}

\author{
Aman Chandi, ${ }^{1}$ David L. Jordan, ${ }^{1}$ Alan C. York, ${ }^{1}$ Jim Burton, ${ }^{2}$ Susana R. Milla-Lewis, \\ Jan Spears, ${ }^{1}$ Jared R. Whitaker, ${ }^{1}$ and Randy Wells ${ }^{1}$ \\ ${ }^{1}$ Department of Crop Science, North Carolina State University, Campus Box 7620, Raleigh, NC 27695-7620, USA \\ ${ }^{2}$ Department of Horticulture Science, North Carolina State University, Campus Box 7609, \\ Raleigh, NC 27695-7609, USA \\ Correspondence should be addressed to David L. Jordan; david_jordan@ncsu.edu
}

Received 6 November 2012; Revised 15 January 2013; Accepted 15 January 2013

Academic Editor: Robert J. Kremer

Copyright (C) 2013 Aman Chandi et al. This is an open access article distributed under the Creative Commons Attribution License, which permits unrestricted use, distribution, and reproduction in any medium, provided the original work is properly cited.

\begin{abstract}
Palmer amaranth is a very problematic weed in several crops in the southern USA due to its competitive ability and resistance to herbicides representing different mechanisms of action. Variation in growth and subsequent interference of North Carolina Palmer amaranth accessions has not been examined. A greenhouse experiment determined response of 15 North Carolina Palmer amaranth accessions to drought stress beginning 15 days after seedling emergence (DAE) for a duration of 3, 5, 7, and 9 days. Following exposure to drought, plants were grown under optimal moisture conditions until harvest at 30 DAE. Five accessions each of glyphosate-resistant (GR), acetolactate synthase inhibitor-resistant (ALSR), and acetolactate synthase inhibitor-susceptible and glyphosate-susceptible (ALSS/GS) were compared. Variation in response to drought stress, based on height and dry weight reduction relative to nonstressed controls, was noted among accessions. Stress for 3 or more days affected height and dry weight. Height and dry weight of GR and ALSR accession groups were reduced less by drought than the ALSS/GS accession group. Results suggest a possible relationship between herbicide resistance and ability of Palmer amaranth to withstand drought stress and thus a possible competitive advantage for resistant accessions under limited moisture availability.
\end{abstract}

\section{Introduction}

The ability of crops and weeds to extract water from soil and their response to moisture stress are key factors in determining the outcome of crop-weed interference under drought [1-6]. Ability to absorb water from soil under limited water availability, water use efficiency, and transpiration vary among crop and weed species [7-11]. For example, water use efficiency of genotypes of vegetable amaranth (Amaranthus tricolor L., A. blitum L., and A. cruentus L.) was not affected by drought stress. However, stress significantly reduced total plant dry mass and leaf area per unit root dry mass and increased root dry mass ratio differently in genotypes [12]. Under limited water conditions, plants respond differently and show a wide range of drought tolerance mechanisms both in terms of morphology and physiology [13]. In another experiment involving vegetable amaranth, significant variation existed among genotypes for transpiration and stomatal conductance which was positively correlated with relative decrease in dry weight across four genotypes [14].

The critical period for crop-weed interference and the extent of crop losses to weed competition can be influenced by soil moisture availability [3]. In some studies [15, 16], yield loss to weeds was less in years with more rainfall or irrigation while the opposite was noted in other research $[17,18]$. A weed-free period of 2 weeks was sufficient to avoid yield loss when soybean (Glycine max (L.) Merr.) competed with common ragweed (Ambrosia artemisiifolia L.) in a dry year, but a 4-week weed-free period was required in years with adequate moisture [19]. In contrast, Jackson et al. [20] and Harrison et al. [21] reported the need for a longer weed-free period when soybean was grown under limited soil moisture conditions. These varying results suggest weed interference is species and environment specific. 
Palmer amaranth (Amaranthus palmeri S. Wats.) is an economically important weed to manage in crop production systems in the southern United States [22] due to its competitive ability, $\mathrm{C}_{4}$ photosynthesis, and higher water use efficiency and growth rate than many other weeds. Resistance to herbicides representing different mechanisms of action, including 5-enolpyruvylshikimate-3-phosphate synthase inhibitors, inhibitors of polymerization of microtubules during mitosis, acetolactate synthase inhibitors, and photosynthetic inhibitors, contributes to the difficulty in managing this weed in several agronomic crops [23-26]. Growth analysis of Palmer amaranth, common waterhemp (Amaranthus rudis Sauer), redroot pigweed (Amaranthus retroflexus L.), and tumble pigweed (Amaranthus albus L.) showed that Palmer amaranth was the tallest, possessed the greatest volume and the greatest amount of branching, had the greatest relative growth rate and net assimilation rate, and produced the greatest leaf area, dry matter, specific leaf area, and leaf area ratio among the four species [26]. The water requirement to fix one gram of $\mathrm{CO}_{2}$ is lower for $\mathrm{C}_{4}$ plants compared to $\mathrm{C}_{3}$ plants, and as a result of these differences $\mathrm{C}_{4}$ weeds carry out photosynthesis more efficiently and can be more competitive than $\mathrm{C}_{3}$ weeds, especially under hot climates [27]. Smooth pigweed (Amaranthus hybridus L.), a $\mathrm{C}_{4}$ plant, had the greatest net photosynthesis rates, net assimilation rates, and water use efficiency based on whole plant as well as on a single leaf basis when comparing soybean and seven weed species under greenhouse conditions [11].

Ability of a particular genotype to produce viable offspring relative to other genotypes in a population is known as the relative fitness of that biotype [28]. Previous research suggests that in some cases herbicide-resistant weed biotypes have a fitness penalty compared with nonresistant wild types. In a population, alleles that carry a larger fitness penalty are less frequent than those with a smaller associated fitness penalty. It is generally assumed that herbicide resistance alleles are infrequent in populations in the absence of selection pressure exerted by herbicide, possibly because of a fitness penalty $[29,30]$. Pederson et al. [31] reported that GR rigid ryegrass (Lolium rigidum Gaudin) produced seeds that were larger in size but fewer in number compared with glyphosate-susceptible plants. Segregating $\mathrm{F}_{2}$ populations of rigid ryegrass generated by crossing resistant and susceptible plants resulted in a decrease in glyphosate resistance in plants $[32,33]$. Maternally inherited triazine resistance resulted in reduced early seedling emergence, early growth, mid-season leaf number, and total above-ground biomass compared with triazine-susceptible populations $[34,35]$. These results suggest that fitness is plastic and can depend on environmental factors [34-36].

Palmer amaranth is particularly troublesome in crops grown on drought-prone soils in North Carolina. This may be because of greater drought tolerance of Palmer amaranth relative to other common weed species, allowing Palmer amaranth to compete more effectively with other weeds and establish monocultures [37]. It is commonly observed that Palmer amaranth is less negatively affected by drought than agronomic crops, and the Palmer amaranth can better recover once drought conditions are relaxed. It is also on these drought-prone soils where GR biotypes of Palmer amaranth were first discovered and where the greatest problems with resistant biotypes occur, leading to the question of whether or not glyphosate resistance and drought tolerance may be related. Ability of ALSR or GR Palmer amaranth populations to recover from drought stress during early season growth when interference with crops is critical has not been reported. A greenhouse experiment was conducted to compare the effect of various durations of imposed drought stress on 15 Palmer amaranth accessions from North Carolina expressing variation in resistance to glyphosate and acetolactate synthase-inhibiting herbicides.

\section{Materials and Methods}

Seeds of Palmer amaranth were randomly collected from 290 fields in North Carolina during the fall of 2005 and were screened for resistance to glyphosate and thifensulfuron [38]. From this seed collection, 15 accessions were selected for the current study (Figure 1). Five accessions were GR, five were ALSR, and five were ALSS/GS. Seeds were planted in excess in round plastic pots $(10 \mathrm{~cm}$ diameter by $12 \mathrm{~cm}$ depth) containing commercial potting mix (Fafard 4P potting mix, Conrad Fafard Inc., Agawam, MA, USA) making sure that all pots contained the same weight of potting mix. Seedlings similar in height and number of leaves were thinned to one per pot 8 DAE. Plants were fertilized with $25 \mathrm{~mL}^{-1}$ of a $4.6 \mathrm{~g} \mathrm{~L}^{-1}$ fertilizer solution (Scotts Starter Fertilizer, The Scotts Company LLC, Marysville, OH, USA) at 10 and 24 DAE to ensure optimum plant growth. Each pot received the same volume of water on a daily basis designed to bring soil to saturation. The greenhouse was maintained at $35 \pm 5^{\circ} \mathrm{C}$, and natural lighting was supplemented for 14 hours daily with metal halide lamps (Hubbell Lighting, Inc., Greenville, SC, USA) delivering $400 \mu \mathrm{mol} \mathrm{m} \mathrm{m}^{-2} \mathrm{~s}^{-1}$.

Beginning 15 DAE, water was withheld in order to induce drought stress for 3, 5, 7, or 9 days. These intervals were selected keeping in mind that weed management decisions are critical during 3-4 weeks after planting. Soil was brought back to full saturation after completion of the stress regimes and was maintained at a moisture status to ensure optimum growth for the remainder of the experiment. Plant height and above-ground dry weight were recorded 30 DAE. Percent reduction in plant height and above-ground dry weight 30 DAE were calculated relative to the nonstressed control for each accession. Percent reduction in these parameters was used to allow statistical comparisons of Palmer amaranth accessions that varied considerably in actual plant height and dry weight. Actual plant height and dry weight for Palmer amaranth controls are presented in Table 1.

The experimental design was the randomized complete block with 10 replications. The experiment was repeated immediately after harvesting the first run. Data were subjected to analysis of variance (Statistical Analysis Systems, version 9.1, SAS Institute Inc., SAS Campus Drive, Cary, NC, USA) appropriate for fifteen (Palmer amaranth accessions) by four (drought stress periods) factorial treatment arrangement to test main effects and interactions. In a second analysis, 
TABle 1: Height and dry weight of Palmer amaranth controls ${ }^{\mathrm{a}}$.

\begin{tabular}{|c|c|c|c|c|c|c|c|c|c|}
\hline \multirow{3}{*}{ Accession } & \multirow{3}{*}{ County } & \multirow{3}{*}{ Resistance } & \multirow{2}{*}{\multicolumn{5}{|c|}{$\begin{array}{c}\text { Height }(\mathrm{cm}) \\
\text { Days of drought stress }\end{array}$}} & \multicolumn{2}{|c|}{ At harvest } \\
\hline & & & & & & & & \multirow{2}{*}{$\begin{array}{l}\text { Height } \\
(\mathrm{cm})\end{array}$} & \multirow{2}{*}{$\begin{array}{l}\text { Dry weight } \\
\left(\text { g plant }^{-1}\right)\end{array}$} \\
\hline & & & 0 & 3 & 5 & 7 & 9 & & \\
\hline \multicolumn{10}{|c|}{ Individual Palmer amaranth accessions ${ }^{\mathrm{b}}$} \\
\hline 1 & Martin & ALSS/GS & 7.0 & 11.0 & 14.0 & 19.0 & 28.0 & 64.0 & 5.0 \\
\hline 2 & Harnett & ALSS/GS & 6.4 & 12.3 & 16.0 & 22.0 & 32.0 & 68.0 & 5.0 \\
\hline 3 & Lenoir & ALSS/GS & 7.0 & 11.3 & 14.0 & 18.0 & 25.0 & 57.0 & 4.3 \\
\hline 4 & Martin & ALSS/GS & 7.0 & 11.3 & 15.0 & 19.3 & 28.0 & 62.4 & 4.1 \\
\hline 5 & Edgecombe & ALSS/GS & 8.3 & 14.0 & 19.0 & 24.4 & 35.0 & 68.0 & 4.6 \\
\hline 6 & Wayne & GR & 8.0 & 13.0 & 17.0 & 21.4 & 30.0 & 62.4 & 4.1 \\
\hline 7 & Hoke & GR & 8.3 & 14.4 & 18.3 & 23.3 & 31.0 & 63.3 & 4.5 \\
\hline 8 & Robeson & GR & 8.0 & 13.3 & 18.0 & 24.1 & 33.4 & 64.1 & 4.6 \\
\hline 9 & Cumberland & GR & 8.0 & 13.4 & 17.3 & 23.0 & 31.0 & 57.4 & 4.0 \\
\hline 10 & Scotland & GR & 8.3 & 16.1 & 21.4 & 27.0 & 33.0 & 60.6 & 4.0 \\
\hline 11 & Robeson & ALSR & 8.1 & 14.0 & 19.0 & 25.1 & 33.3 & 64.1 & 4.0 \\
\hline 12 & Johnston & ALSR & 7.0 & 12.7 & 17.0 & 23.0 & 32.3 & 68.0 & 4.1 \\
\hline 13 & Robeson & ALSR & 9.4 & 16.2 & 20.2 & 25.0 & 31.4 & 58.3 & 4.0 \\
\hline 14 & Sampson & ALSR & 9.0 & 14.0 & 17.4 & 23.0 & 31.0 & 60.3 & 3.4 \\
\hline 15 & Edgecombe & ALSR & 8.2 & 13.4 & 17.0 & 22.0 & 26.2 & 53.0 & 3.4 \\
\hline \multicolumn{10}{|c|}{ Palmer amaranth accessions grouped by response to herbicide ${ }^{c}$} \\
\hline 1 & & ALSS/GS & 7.0 & 12.0 & 15.3 & 21.0 & 29.4 & 63.1 & 4.5 \\
\hline 2 & & GR & 8.0 & 14.0 & 18.3 & 24.0 & 31.4 & 62.0 & 4.2 \\
\hline 3 & & ALSR & 8.2 & 14.0 & 18.0 & 23.3 & 31.0 & 61.0 & 3.7 \\
\hline
\end{tabular}

a Data are pooled over experiments.

${ }^{\mathrm{b}}$ Consists of fifteen Palmer amaranth accessions.

${ }^{\mathrm{C}}$ Consists of a group of 5 acetolactate synthase-inhibitor susceptible and glyphosate-susceptible (ALSS/GS), a group of 5 acetolactate synthase inhibitor-resistant (ALSR), and a group of 5 glyphosate-resistant (GR) Palmer amaranth accessions.

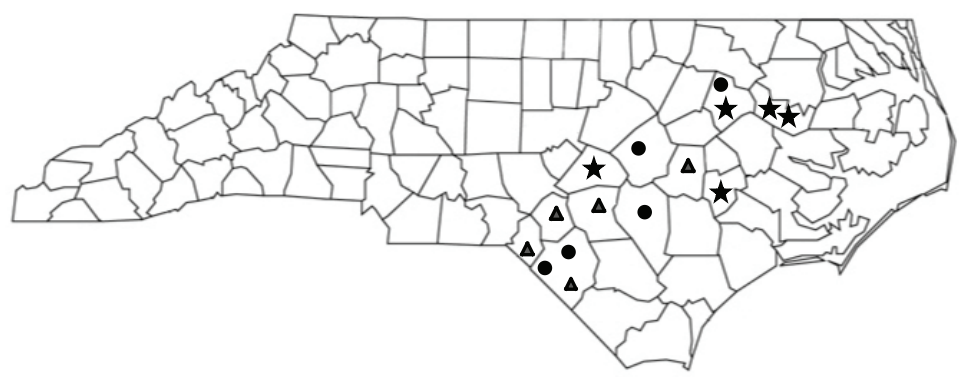

$\star$ GS/ALSS (Edgecombe, Harnett, Lenoir, and Martin counties)

$\Delta$ GR (Cumberland, Hoke, Scotland, and Wayne counties)

- ALSR (Edgecombe, Johnston, Robeson, and Sampson counties)

FIgURE 1: Locations of Palmer amaranth accessions collected during fall of 2005 used in the present study.

Palmer amaranth accessions were grouped based on confirmed resistance to glyphosate (GR), resistance to acetolactate synthase inhibitors (ALSR), and susceptibility to both of these mechanisms of action (ALSS/GS). Data were subjected to analysis of variance considering the factorial arrangement of three levels of accession grouping and four levels of drought stress duration. Due to lack of interaction, the data were pooled over the two runs of the experiment. Means of significant main effects and interactions were separated using Fisher's protected LSD test at $P \leq 0.10$. Percent reduction in height and dry weight were also regressed against duration of stress in SigmaPlot 12.0 using quadratic equation $y=$ $a x^{2}+b x+c$, where $y=$ percent reduction in height or dry weight, $a, b$, and $c$ are constants, and $x=$ duration of drought stress in days. Furthermore, linear regression was fit to the percent reduction in height of 15 Palmer amaranth accessions 
and 3 accession groups over varying periods of drought stress for all the replications in SAS. The slopes thus obtained were compared using analysis of variance.

In a separate experiment carried out alongside the previously described one, photosynthetic assimilation $(\mu \mathrm{mol}$ $\left.\mathrm{CO}_{2} \mathrm{~m}^{-2} \mathrm{~s}^{-1}\right)$ and stomatal conductance $\left(\mu \mathrm{mol} \mathrm{H} \mathrm{H}_{2} \mathrm{O} \mathrm{m}^{-2} \mathrm{~s}^{-1}\right)$ were determined for one ALSS/GS accession following 3, 5,7 , and 9 days of drought stress initiated 15 DAE. These measurements were recorded to document the physiological stress associated with the drought stress regimes and to relate the physiological stress with associated height and dry weight reductions in order to provide an estimate of the degree of drought stress imposed by treatments. Recording these values was not possible for all combinations of Palmer amaranth accessions and drought treatments. The fourth fully expanded leaf from the top of each plant was used for measurements which were made between 10:00 and 14:00 hours EST using a portable photosynthesis system (LI-6400 Portable Photosynthesis System, LI-COR Biosciences, P.O. Box 4425, Lincoln, NE, USA) and a leaf chamber fluorometer equipped with version 6.2 software. Each measurement was taken over a 30-second period of time. There were five replicate plants per treatment and six measurements were taken per plant. The measurements were averaged over plants. The experiment was repeated immediately after completion of the first run. Data for photosynthetic assimilation and stomatal conductance were subjected to analysis of variance, and means of significant main effects were separated using Fisher's protected LSD test at $P \leq 0.10$. Percent reduction in photosynthetic assimilation and stomatal conductance were regressed against duration of stress in SigmaPlot 12.0 using linear equation $y=b x+c$, where $y=$ percent reduction in photosynthetic assimilation or stomatal conductance, $b$ and $c$ are constants, and $x=$ duration of drought stress in days.

\section{Results and Discussion}

The main effects of accession and duration of drought stress and the interaction of these factors were significant for percent reduction in height and dry weight when all 15 Palmer amaranth accessions were analyzed individually (Table 2). Considerable differences in response to varying periods of drought existed among accessions (Table 3). For example, with 9 days of drought stress, height reduction ranged from $8 \%$ to $25 \%$ while dry weight reduction ranged from $9 \%$ to $47 \%$. With all of the ALSS/GS accessions, dry weight reduction was similar regardless of duration of drought except Martin and Edgecombe at 9 days of drought stress. With the exception of the Hoke GR accession, all herbicide-resistant accessions had similar and small dry weight reductions following exposure to 3 to 5 days of drought. Reduction in dry weight increased with 7 to 9 days of drought for all GR accessions except for GR accession from Wayne County. This suggested that the herbicide-resistant accessions could better withstand short-term drought stress than the susceptible accessions. When pooled over the duration of drought stress, reduction in height and dry weight for the Palmer amaranth accessions at harvest ranged from $5 \%$ to $15 \%$ and $12 \%$ to $29 \%$, respectively (Table 4 ). The slopes of regression lines for the
TABLE 2: $P>F$ for percent reduction in height and dry weight of 15 Palmer amaranth accessions 30 days after emergence ${ }^{\mathrm{a}}$.

\begin{tabular}{|c|c|c|}
\hline \multirow[t]{2}{*}{ Treatment factors } & Height & Dry weight \\
\hline & \multicolumn{2}{|c|}{$P$ value } \\
\hline \multicolumn{3}{|c|}{ Individual Palmer amaranth accessions ${ }^{\mathrm{b}}$} \\
\hline Accession & $<0.0001$ & $<0.0001$ \\
\hline Drought stress & $<0.0001$ & $<0.0001$ \\
\hline Accession $\times$ drought stress & 0.0173 & $<0.0001$ \\
\hline Coefficient of variation (\%) & 105 & 82 \\
\hline \multicolumn{3}{|c|}{ Palmer amaranth accessions grouped by response to herbicide ${ }^{c}$} \\
\hline Accession group & 0.0733 & 0.0060 \\
\hline Drought stress & $<0.0001$ & $<0.0001$ \\
\hline $\begin{array}{l}\text { Accession group } \times \text { drought } \\
\text { stress }\end{array}$ & 0.6892 & 0.3886 \\
\hline Coefficient of variation (\%) & 108 & 87 \\
\hline \multicolumn{3}{|c|}{ Data are pooled over experiments. } \\
\hline \multicolumn{3}{|c|}{$\begin{array}{l}{ }^{b} \text { Consists of fifteen Palmer amaranth accessions. } \\
\text { c Consists of a group of } 5 \text { acetolactate synthase-inhibitor susceptible and gly } \\
\text { phosate-susceptible (ALSS/GS), a group of } 5 \text { acetolactate synthase inhibitor } \\
\text { resistant (ALSR), and a group of } 5 \text { glyphosate-resistant (GR) Palmer ama } \\
\text { ranth accessions. }\end{array}$} \\
\hline
\end{tabular}

percentage of reduction in height were similar for 13 of the 15 Palmer amaranth accessions. This suggested similar rate of reduction in height for majority of the accessions of Palmer amaranth used in this study. Differences among accessions for these variables may well be expected given the degree of phenotypic variation often observed among Palmer amaranth biotypes [39].

The primary objective of this experiment was to determine the relationship between herbicide resistance expression and response to drought stress. When accessions were segregated into three groups according to their resistance characteristics (GR, ALSR, and ALSS/GS), the interaction of accession group by duration of drought stress was not significant for height and dry weight reductions (Table 1). However, the main effect of accession grouping was significant for percent reduction in height $(P=0.0733)$ and dry weight $(P=0.0060)$.

Increasing duration of drought stress resulted in greater reductions in Palmer amaranth height and dry weight. Additionally, drought stress had a greater effect on dry weight than on height (Figure 2). Averaged over resistance groupings, drought stress for $3,5,7$, and 9 days caused $6 \%, 8 \%, 12 \%$, and $18 \%$ reduction in height and $13 \%, 16 \%, 22 \%$, and $32 \%$ reduction in dry weight, respectively

Differences among accession groupings were noted for reduction in height and dry weight (Table 5). Both height and dry weight of the ALSR and GR groups were less affected by drought stress than the ALSS/GS group. Percentage of dry weight reduction for GR and ALSR groups was 20\% compared with $23 \%$ for the ALSS/GS group. Percentage of reduction in height of ALSR and GR was 10\% compared with $12 \%$ for the ALSS/GS group. Lack of significant differences in the slopes of reduction in height among the three accession groups suggested similar rates of height reduction over duration of drought stress. 
TABLE 3: Percent reduction in height and dry weight of 15 Palmer amaranth accessions at harvest (30 DAE) as affected by the interaction of accession and duration of drought stress ${ }^{\mathrm{a}, \mathrm{b}}$.

\begin{tabular}{|c|c|c|c|c|c|c|c|c|c|c|}
\hline \multirow{4}{*}{ Accession } & \multirow{4}{*}{ County } & \multirow{4}{*}{ Resistance } & \multicolumn{4}{|c|}{ Height } & \multicolumn{4}{|c|}{ Dry weight } \\
\hline & & & \multicolumn{4}{|c|}{ Duration of drought stress (days) } & \multicolumn{4}{|c|}{ Duration of drought stress (days) } \\
\hline & & & 3 & 5 & 7 & 9 & 3 & 5 & 7 & 9 \\
\hline & & & \multicolumn{8}{|c|}{$\%$} \\
\hline 1 & Martin & ALSS/GS & 3 op & $7 \mathrm{k}-\mathrm{p}$ & $12 \mathrm{~g}-1$ & $20 \mathrm{~b}-\mathrm{e}$ & $15 \mathrm{~g}-\mathrm{p}$ & $21 \mathrm{f}-\mathrm{k}$ & $24 \mathrm{~d}-\mathrm{h}$ & $16 \mathrm{~g}-\mathrm{O}$ \\
\hline 2 & Harnett & ALSS/GS & $7 \mathrm{k}-\mathrm{p}$ & $14 \mathrm{e}-\mathrm{j}$ & $20 \mathrm{~b}-\mathrm{e}$ & $16 \mathrm{c}-\mathrm{h}$ & $18 \mathrm{f}-\mathrm{n}$ & $23 \mathrm{~d}-\mathrm{i}$ & $22 \mathrm{e}-\mathrm{j}$ & $22 \mathrm{e}-\mathrm{j}$ \\
\hline 3 & Lenoir & ALSS/GS & $4 n-p$ & $9 \mathrm{i}-\mathrm{o}$ & $13 \mathrm{f}-\mathrm{k}$ & $20 \mathrm{~b}-\mathrm{e}$ & $14 \mathrm{~h}-\mathrm{q}$ & $21 \mathrm{f}-\mathrm{k}$ & $17 \mathrm{~g}-\mathrm{o}$ & $21 \mathrm{f}-\mathrm{k}$ \\
\hline 4 & Martin & ALSS/GS & $61-p$ & $4 \mathrm{n}-\mathrm{p}$ & $10 \mathrm{~h}-\mathrm{n}$ & $19 \mathrm{~b}-\mathrm{f}$ & $17 \mathrm{~g}-\mathrm{o}$ & $15 \mathrm{~g}-\mathrm{p}$ & $15 \mathrm{~g}-\mathrm{p}$ & $12 \mathrm{j}-\mathrm{q}$ \\
\hline 5 & Edgecombe & ALSS/GS & $10 \mathrm{~h}-\mathrm{n}$ & $8 j-p$ & $9 \mathrm{i}-\mathrm{o}$ & $24 \mathrm{ab}$ & $24 \mathrm{~d}-\mathrm{h}$ & $17 \mathrm{~g}-\mathrm{o}$ & $16 \mathrm{~g}-\mathrm{o}$ & $9 \mathrm{~m}-\mathrm{q}$ \\
\hline 6 & Wayne & GR & $11 \mathrm{~g}-\mathrm{m}$ & $8 j-p$ & $11 \mathrm{~g}-\mathrm{m}$ & $22 \mathrm{bc}$ & $15 \mathrm{~g}-\mathrm{p}$ & $11 \mathrm{k}-\mathrm{q}$ & $15 \mathrm{~g}-\mathrm{p}$ & $13 \mathrm{i}-\mathrm{q}$ \\
\hline 7 & Hoke & GR & $7 \mathrm{k}-\mathrm{p}$ & $16 c-h$ & $11 \mathrm{~g}-\mathrm{m}$ & $22 c$ & $21 \mathrm{f}-\mathrm{k}$ & $23 \mathrm{~d}-\mathrm{i}$ & $28 \mathrm{c}-\mathrm{f}$ & $47 \mathrm{a}$ \\
\hline 8 & Robeson & GR & 3 op & $5 \mathrm{~m}-\mathrm{p}$ & $11 \mathrm{~g}-\mathrm{m}$ & $16 \mathrm{c}-\mathrm{h}$ & $8 \mathrm{n}-\mathrm{q}$ & $10 \mathrm{l}-\mathrm{q}$ & $28 \mathrm{c}-\mathrm{f}$ & $33 \mathrm{~b}-\mathrm{d}$ \\
\hline 9 & Cumberland & GR & 3 op & $5 \mathrm{~m}-\mathrm{p}$ & $5 \mathrm{~m}-\mathrm{p}$ & $8 j-p$ & $5 \mathrm{pq}$ & $10 \mathrm{l}-\mathrm{q}$ & $13 \mathrm{i}-\mathrm{q}$ & $21 \mathrm{f}-\mathrm{k}$ \\
\hline 10 & Scotland & GR & $5 \mathrm{~m}-\mathrm{p}$ & $2 \mathrm{p}$ & $15 \mathrm{~d}-\mathrm{i}$ & $17 c-g$ & $11 \mathrm{k}-\mathrm{q}$ & $4 \mathrm{q}$ & $25 \mathrm{~d}-\mathrm{g}$ & $33 b-d$ \\
\hline 11 & Robeson & ALSR & $9 \mathrm{i}-\mathrm{o}$ & $8 j-p$ & $12 \mathrm{~g}-1$ & $21 \mathrm{~b}-\mathrm{d}$ & $16 \mathrm{~g}-\mathrm{o}$ & $16 \mathrm{~g}-\mathrm{o}$ & $19 \mathrm{f}-\mathrm{m}$ & $38 \mathrm{a}-\mathrm{c}$ \\
\hline 12 & Johnston & ALSR & $8 j-p$ & $7 \mathrm{k}-\mathrm{p}$ & $11 \mathrm{~g}-\mathrm{m}$ & $25 \mathrm{ab}$ & 5 pq & $5 \mathrm{pq}$ & $16 \mathrm{~g}-\mathrm{o}$ & $38 \mathrm{a}-\mathrm{c}$ \\
\hline 13 & Robeson & ALSR & $5 \mathrm{~m}-\mathrm{p}$ & $7 \mathrm{k}-\mathrm{p}$ & $8 j-p$ & $17 c-g$ & $15 \mathrm{~g}-\mathrm{p}$ & $19 \mathrm{f}-\mathrm{m}$ & $32 \mathrm{~b}-\mathrm{e}$ & $39 \mathrm{ab}$ \\
\hline 14 & Sampson & ALSR & $8 j-p$ & $11 \mathrm{~g}-\mathrm{m}$ & $61-p$ & $17 c-g$ & $15 \mathrm{~g}-\mathrm{p}$ & $14 \mathrm{~h}-\mathrm{q}$ & $101-q$ & $24 \mathrm{~d}-\mathrm{h}$ \\
\hline 15 & Edgecombe & ALSR & $4 \mathrm{n}-\mathrm{p}$ & $9 \mathrm{i}-\mathrm{o}$ & $14 \mathrm{e}-\mathrm{j}$ & $14 \mathrm{e}-\mathrm{j}$ & $13 \mathrm{i}-\mathrm{q}$ & $20 \mathrm{f}-1$ & $16 \mathrm{~g}-\mathrm{o}$ & $24 \mathrm{~d}-\mathrm{h}$ \\
\hline
\end{tabular}

Data are pooled over experiments.

${ }^{\mathrm{b}}$ Means within a parameter followed by the same letter are not significantly different according to Fisher's Protected LSD test at $P \leq 0.10$.

TABLE 4: Percent reduction in height and dry weight 30 days after emergence and the slopes of regression lines for percentage of reduction in height of 15 Palmer amaranth accessions ${ }^{\mathrm{a}}$.

\begin{tabular}{|c|c|c|c|c|c|}
\hline \multirow{2}{*}{ Accession } & \multirow{2}{*}{ County } & \multirow{2}{*}{ Resistance $^{b}$} & Height & Dry weight & \multirow{2}{*}{$\begin{array}{c}\text { Slope } \\
\text { \% reduction day }\end{array}$} \\
\hline & & & \multicolumn{2}{|c|}{$\%$ reduction plant ${ }^{-1}$} & \\
\hline 1 & Martin & ALSS/GS & $11 \mathrm{~b}-\mathrm{d}$ & $27 \mathrm{~b}$ & $5.5 \mathrm{a}$ \\
\hline 2 & Harnett & ALSS/GS & $15 \mathrm{a}$ & $29 \mathrm{ab}$ & $4.5 \mathrm{abc}$ \\
\hline 3 & Lenoir & ALSS/GS & $12 \mathrm{a}-\mathrm{d}$ & $21 \mathrm{~d}$ & $3.2 \mathrm{c}$ \\
\hline 4 & Martin & ALSS/GS & $10 \mathrm{~cd}$ & $16 \mathrm{e}-\mathrm{g}$ & $3.5 \mathrm{c}$ \\
\hline 5 & Edgecombe & ALSS/GS & $12 \mathrm{a}-\mathrm{d}$ & $22 \mathrm{~cd}$ & $3.3 c$ \\
\hline 6 & Wayne & GR & $13 a-c$ & $14 \mathrm{fg}$ & $4.0 \mathrm{abc}$ \\
\hline 7 & Hoke & GR & $14 \mathrm{ab}$ & $33 \mathrm{a}$ & $3.6 \mathrm{bc}$ \\
\hline 8 & Robeson & GR & $9 \mathrm{~d}$ & $20 \mathrm{de}$ & $3.4 \mathrm{c}$ \\
\hline 9 & Cumberland & GR & $5 \mathrm{e}$ & $12 \mathrm{~g}$ & $3.2 \mathrm{c}$ \\
\hline 10 & Scotland & GR & $10 \mathrm{~cd}$ & $18 \mathrm{~d}-\mathrm{f}$ & $3.3 c$ \\
\hline 11 & Robeson & ALSR & $13 a-c$ & $22 \mathrm{~cd}$ & $4.7 \mathrm{abc}$ \\
\hline 12 & Johnston & ALSR & $13 a-c$ & $16 \mathrm{e}-\mathrm{g}$ & $5.1 \mathrm{ab}$ \\
\hline 13 & Robeson & ALSR & $9 \mathrm{~d}$ & $26 \mathrm{bc}$ & $3.6 \mathrm{bc}$ \\
\hline 14 & Sampson & ALSR & $11 \mathrm{~b}-\mathrm{d}$ & $16 \mathrm{e}-\mathrm{g}$ & $3.3 c$ \\
\hline 15 & Edgecombe & ALSR & $11 \mathrm{~b}-\mathrm{d}$ & $18 \mathrm{~d}-\mathrm{f}$ & $3.8 \mathrm{bc}$ \\
\hline
\end{tabular}

${ }^{a}$ Data are pooled over experiments and duration of drought stress. Means within a parameter followed by the same letter are not significantly different according to Fisher's Protected LSD test at $P \leq 0.10$.

${ }^{b}$ Abbreviations: ALSS/GS: acetolactate synthase-inhibitor susceptible and glyphosate-susceptible accession; ALSR: acetolactate synthase inhibitor-resistant accession; GR: glyphosate-resistant accession.

Photosynthesis rate and stomatal conductance were measured in a separate experiment conducted alongside the above mentioned study. These measurements were taken on one ALSS/GS accession of Palmer amaranth at 3, 5, 7, and 9 days after initiation of drought stress to quantify the effect of drought stress on physiological processes that could result in reduced growth. Although more informative, recording these values for all 15 accessions would have been difficult under the series of drought treatments. Drought stress of 3 days or more reduced photosynthesis and stomatal conductance significantly (Table 6). However, visually wilting was observed only with 5 or more days of drought stress. Similar to the results for 


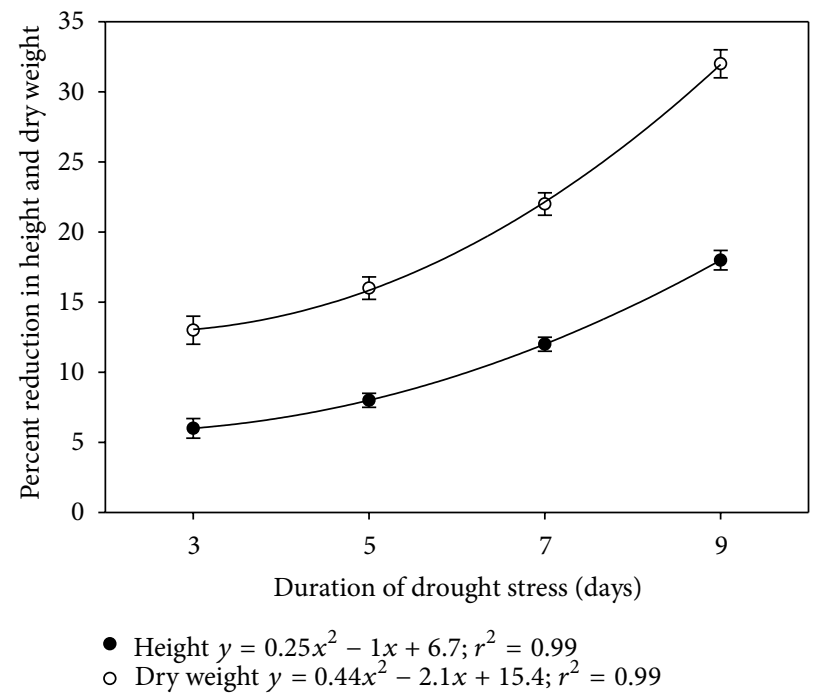

FIGURE 2: Percent reduction in plant height and dry weight as affected by the duration of drought stress in days. Data pooled over accessions. Points are means \pm S.E.

TABle 5: Percent reduction in height and dry weight 30 days after emergence and slopes of regression lines for percentage of reduction in height of 15 Palmer amaranth accessions when accessions were grouped as acetolactate synthase inhibitor-susceptible and glyphosate-susceptible (ALSS/GS), acetolactate synthase inhibitorresistant (ALSR), and glyphosate-resistant (GR) .

\begin{tabular}{lccc}
\hline Accession grouping & $\begin{array}{c}\text { Height } \\
\text { \% reduction plant }\end{array}$ & $\begin{array}{c}\text { Dry weight } \\
\text { \% reduction day }\end{array}$ \\
\hline ALSS/GS & $12 \mathrm{a}$ & $23 \mathrm{a}$ & $4.0 \mathrm{a}$ \\
GR & $10 \mathrm{~b}$ & $20 \mathrm{~b}$ & $4.5 \mathrm{a}$ \\
ALSR & $10 \mathrm{~b}$ & $20 \mathrm{~b}$ & $4.1 \mathrm{a}$ \\
\hline
\end{tabular}

${ }^{a}$ Data are pooled over experiments and duration of drought stress. Means within a parameter followed by the same letter are not significantly different according to Fisher's protected LSD test at $P \leq 0.10$.

height and dry weight reductions (Figure 2), increasing duration of drought stress progressively reduced photosynthesis rate and stomatal conductance (Figure 3). Drought stress for $3,5,7$, and 9 days caused $14 \%, 37 \%, 60 \%$, and $83 \%$ reduction in photosynthesis and $10 \%, 40 \%, 70 \%$, and $99 \%$ reduction in stomatal conductance, respectively. Reductions in rate of photosynthesis and stomatal conductance appeared to be closely correlated with reductions in height and dry weight.

\section{Conclusions}

The number of accessions in each resistance grouping was limited to five in this study. A more comprehensive screening of a larger number of accessions with drought stress extended beyond 9 days would be more informative in defining relationships between herbicide resistance and ability to recover from drought stress. However, no other research is published in the peer-reviewed literature addressing this topic for Palmer amaranth. This experiment was conducted during the first 30 days after weed emergence when weeds, including Palmer amaranth, have the greatest potential to
TABLE 6: $P>F$ for influence of drought stress on photosynthesis and stomatal conductance of an acetolactate synthase inhibitor-susceptible and glyphosate-susceptible Palmer amaranth accession ${ }^{\mathrm{a}}$.

\begin{tabular}{lcc}
\hline Duration of stress & $\begin{array}{c}\text { Photosynthesis } \\
\mu \mathrm{mol} \mathrm{CO} \mathrm{m}^{-2} \mathrm{~s}^{-1}\end{array}$ & $\begin{array}{c}\text { Stomatal conductance } \\
\mathrm{mol} \mathrm{H}_{2} \mathrm{O} \mathrm{m}^{-2} \mathrm{~s}^{-1}\end{array}$ \\
\hline Days & \multicolumn{2}{c}{$P$ value } \\
\hline 3 & 0.0151 & 0.0325 \\
5 & 0.0261 & 0.0321 \\
7 & 0.0368 & 0.0270 \\
9 & 0.0010 & $<0.0001$ \\
\hline
\end{tabular}

${ }^{\mathrm{a}}$ Data are pooled over experiments.

impact growth, development, and yield of crops [19-21, 4043]. Differences observed with accession groupings in this experiment, although small, suggest a possible relationship between herbicide resistance and greater ability of Palmer amaranth to withstand drought stress. This could result in a competitive advantage for Palmer amaranth resistant to ALS inhibitors and glyphosate. Previous research with limited accessions of glyphosate resistant and glyphosate susceptible indicates both advantages and disadvantages of glyphosate resistance in terms of interference and response to herbicides other than glyphosate $[44,45]$. Future research with a much larger pool of accessions from a more diverse geographical area would provide a clearer understanding of the impact of glyphosate resistance on biology of Palmer amaranth. Use of sister lines from a common parent population to compare potential aspects influencing fitness would also be informative.

\section{Conflict of Interests}

None of the authors has a conflict of interests in terms of the products mentioned in the paper. 


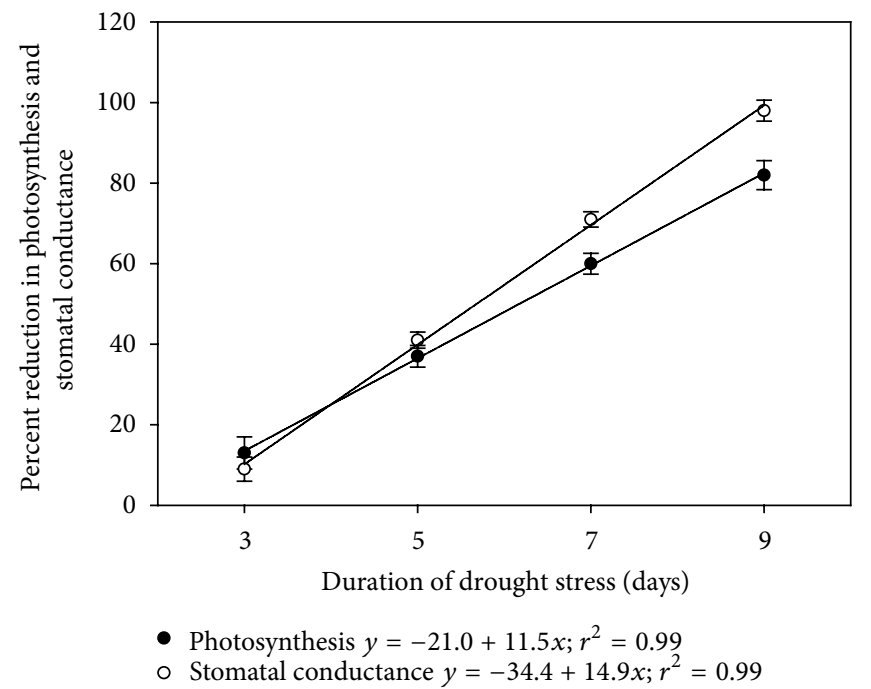

Figure 3: Percent reduction in photosynthesis and stomatal conductance of an acetolactate synthase-sensitive and glyphosate-sensitive (ALSS/GS) accession as affected by duration of drought stress in days. Points are means \pm S.E.

\section{Acknowledgments}

Syngenta Crop Protection and Monsanto Company provided partial financial support. Dr. Fitz Booker, USDA-ARS Plant Physiologist and Professor of Crop Science, North Carolina State University, USA, provided the LI-6400 Portable Photosynthesis System and valuable suggestions for the experiment. Erin Silva, Biological Science Technician (USDA-ARS), assisted with the instrumentation.

\section{References}

[1] J. K. A. Bleasdale, "Studies on plant competition," in The Biology of Weeds, J. L. Harper, Ed., pp. 133-142, Blackwell Scientific Publishers, Oxford, UK, 1960.

[2] A. G. Ogg Jr., R. H. Stephens, and D. R. Gealy, "Interference between mayweed chamomile (Anthemis cotula) and pea (Pisum sativum) is affected by form of interference and soil water regime," Weed Science, vol. 42, no. 4, pp. 579-585, 1994.

[3] D. T. Patterson, "Effects of environmental stress on weed/crop interactions," Weed Science, vol. 43, no. 3, pp. 483-490, 1995.

[4] M. S. Riffle, D. S. Murray, J. F. Stone, and D. L. Weeks, "Soil-water relations and interference between devil's-claw (Proboscidea louisianica) and cotton (Gossypium hirsutum)," Weed Science, vol. 38, no. 1, pp. 39-44, 1990.

[5] A. F. Wiese and C. W. Van Diver, "Soil moisture effects on competitive ability of weeds," Weed Science, vol. 18, no. 4, pp. 518-519, 1970.

[6] R. L. Zimdahl, Weed-Crop Competition A Review, Blackwell Publishers, Ames, Iowa, USA, 2nd edition, 2004.

[7] R. J. Aldrich, Weed-Crop Ecology: Principles in Weed Management, Breton Publishers, North Scituate, Mass, USA, 1984.

[8] R. D. Geddes, H. D. Scott, and L. R. Oliver, "Growth and water use by common cocklebur (Xanthium pensylvanicum) and soybean (Glycine max) under field conditions," Weed Science, vol. 27, no. 2, pp. 206-212, 1979.

[9] J. L. Harper, Population Biology of Plants, Academic Press, London, UK, 1977.
[10] D. T. Patterson, "Responses of soybean (Glycine max) and three $\mathrm{C}_{4}$ grass weeds to $\mathrm{CO}_{2}$ enrichment during drought," Weed Science, vol. 34, no. 2, pp. 203-210, 1986.

[11] D. T. Patterson and E. P. Flint, "Comparative water relations, photosynthesis, and growth of soybean (Glycine max) and seven associated weeds," Weed Science, vol. 31, no. 3, pp. 318-323, 1983.

[12] F. Liu and H. Stützel, "Biomass partitioning, specific leaf area, and water use efficiency of vegetable amaranth (Amaranthus spp.) in response to drought stress," Scientia Horticulturae, vol. 102, no. 1, pp. 15-27, 2004.

[13] A. Blum, "Crop responses to drought and the interpretation of adaptation," Plant Growth Regulation, vol. 20, no. 2, pp. 135-148, 1996.

[14] F. Liu and H. Stützel, "Leaf expansion, stomatal conductance, and transpiration of vegetable amaranth (Amaranthus sp.) in response to soil drying," Journal of the American Society for Horticultural Science, vol. 127, no. 5, pp. 878-883, 2002.

[15] F. L, Young, D. L. Wyse, and R. J. Jones, "Effect of irrigation on quackgrass (Agropyron repens) interference in soybean (Glycine max)," Weed Science, vol. 31, no. 5, pp. 720-727, 1983.

[16] F. L. Young, D. L. Wyse, and R. J. Jones, "Quackgrass (Agropyron repens) interference in corn (Zea mays)," Weed Science, vol. 32, no. 2, pp. 226-234, 1984.

[17] D. A. Mortensen and H. D. Coble, "The influence of soil water content on common cocklebur (Xanthium strumarium) interference in soybeans (Glycine max)," Weed Science, vol. 37, no. 1, pp. $76-83,1989$.

[18] S. E. Weaver, "Factors affecting threshold levels and seed production of jimsonweed (Datura stramonium L.) in soybeans (Glycine max (L.) Merr.)," Weed Research, vol. 26, no. 3, pp. 215224, 1986.

[19] H. D. Coble, F. M. Williams, and R. L. Ritter, "Common ragweed (Ambrosia artemisiifolia L.) interference in soybeans (Glycine max)," Weed Science, vol. 29, no. 3, pp. 339-342, 1981.

[20] L. A. Jackson, G. Kapusta, and D. J. Schutte Mason, "Effect of duration and type of natural weed infestations on soybean yield," Agronomy Journal, vol. 77, no. 5, pp. 225-729, 1985. 
[21] S. K. Harrison, C. S. Williams, and L. M. Wax, "Interference and control of giant foxtail (Setaria faberi) in soybeans (Glycine max)," Weed Science, vol. 33, no. 2, pp. 203-208, 1985.

[22] T. M. Webster, "Weed survey-southern states," Proceedings Southern Weed Science Society, vol. 62, pp. 509-524, 2009.

[23] C. C. Black, T. M. Chen, and R. H. Brown, "Biochemical basis for plant competition,” Weed Science, vol. 17, no. 3, pp. 338-344, 1969.

[24] A. S. Culpepper, T. M. Webster, L. M. Sosnoskie, and A. C. York, "Glyphosate-resistant Palmer amaranth in the United States," in Glyphosate Resistance in Crops and Weeds: History, Development, and Management, V. K. Nandula, Ed., pp. 195-212, John Wiley \& Sons, Hoboken, NJ, USA, 2010.

[25] I. Heap, "The International Survey of Herbicide Resistant Weeds," 2012, http://www.weedscience.org.

[26] M. J. Horak and T. M. Loughin, "Growth analysis of four Amaranthus species," Weed Science, vol. 48, no. 3, pp. 347-355, 2000.

[27] S. Radosevich, J. Holt, and C. Ghersa, Weed Ecology: Implications for Management, John Wiley \& Sons, New York, NY, USA, 2nd edition, 1997.

[28] C. Preston, A. M. Wakelin, F. C. Dolman, Y. Bostamam, and P. Boutsalis, "A decade of glyphosate-resistant lolium around the world: mechanisms, genes, fitness, and agronomic management," Weed Science, vol. 57, no. 4, pp. 435-441, 2009.

[29] M. A. Jasieniuk, A. L. Brûl-Babel, and I. N. Morrison, "The evolution and genetics of herbicide resistance in weeds," Weed Science, vol. 44, no. 1, pp. 176-193, 1996.

[30] C. Preston and S. B. Powles, "Evolution of herbicide resistance in weeds: initial frequency of target site-based resistance to acetolactate synthase-inhibiting herbicides in Lolium rigidum," Heredity, vol. 88, no. 1, pp. 8-13, 2002.

[31] B. P. Pedersen, P. Neve, C. Andreasen, and S. B. Powles, "Ecological fitness of a glyphosate-resistant Lolium rigidum population: growth and seed production along a competition gradient," Basic and Applied Ecology, vol. 8, no. 3, pp. 258-268, 2007.

[32] C. Preston and A. M. Wakelin, "Resistance to glyphosate from altered herbicide translocation patterns," Pest Management Science, vol. 64, no. 4, pp. 372-376, 2008.

[33] A. M. Wakelin and C. Preston, "The cost of glyphosate resistance: is there a fitness penalty associated with glyphosate resistance in annual ryegrass," in Managing Weeds in a Changing Climate, C. Preston, J. H. Watts, and N. D. Crossman, Eds., pp. 515-518, Weed Management Society of South Australia, Torrens Park, South Australia, 2006.

[34] N. Jordan, "Effects of the triazine-resistance mutation on fitness in Amaranthus hybridus (smooth pigweed)," Journal of Applied Ecology, vol. 33, no. 1, pp. 141-150, 1996.

[35] N. Jordan, "Fitness effects of the triazine resistance mutation in Amaranthus hybridus: relative fitness in maize and soyabean crops," Weed Research, vol. 39, no. 6, pp. 493-505, 1999.

[36] R. Cousens and M. Mortimer, Dynamics of Weed Populations, Cambridge University Press, West Nyack, NY, USA, 1995.

[37] J. Ehleringer, "Ecophysiology of Amaranthus palmeri, a sonoran desert summer annual," Oecologia, vol. 57, no. 1-2, pp. 107-112, 1983.

[38] J. R. Whitaker, Distribution, biology, and management of glyphosate-resistant Palmer amaranth in North Carolina [Ph.D. dissertation], North Carolina State University, Raleigh, NC, USA, 2009.

[39] T. E. Klingaman and L. R. Oliver, "Palmer amaranth (Amaranthus palmeri) interference in soybeans (Glycine max)," Weed Science, vol. 42, no. 4, pp. 523-527, 1994.
[40] B. Bukun, "Critical periods for weed control in cotton in Turkey," Weed Research, vol. 44, no. 5, pp. 404-412, 2004.

[41] A. S. Culpepper and A. C. York, "Weed management in glyphosate-tolerant cotton," Journal of Cotton Science, vol. 2, no. 4, pp. 174-185, 1998.

[42] B. J. Fast, S. W. Murdock, R. L. Farris, J. B. Willis, and D. S. Murray, "Critical timing of palmer amaranth (Amaranthus palmeri) removal in second-generation glyphosate-resistant cotton," Journal of Cotton Science, vol. 13, no. 1, pp. 32-36, 2009.

[43] D. Papamichail, I. Eleftherohorinos, R. Froud-Williams, and F. Gravanis, "Critical periods of weed competition in cotton in Greece," Phytoparasitica, vol. 30, no. 1, pp. 105-111, 2002.

[44] A. Chandi, D. L. Jordan, A. C. York et al., "Interference of selected Palmer amaranth (Amaranthus palmeri) populations in soybean (Glycine max)," International Journal of Agronomy, vol. 2012, Article ID 168267, 7 pages, 2012.

[45] A. Chandi, D. L. Jordan, A. C. York et al., "Interference and control of glyphosate-resistant and -susceptible Palmer amaranth (Amaranthus palmeri) populations under greenhouse conditions," Weed Science, Article ID WS-D-12-00063, 2013. 


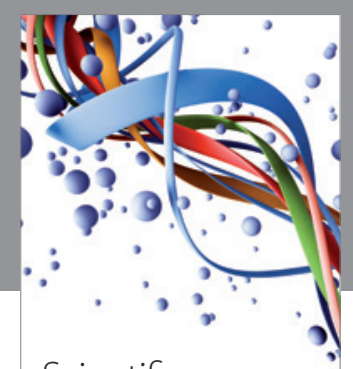

Scientifica
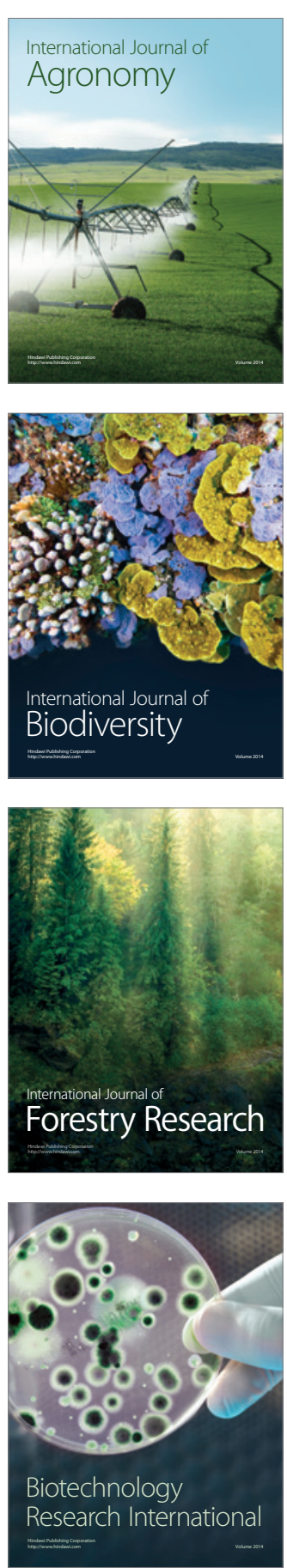
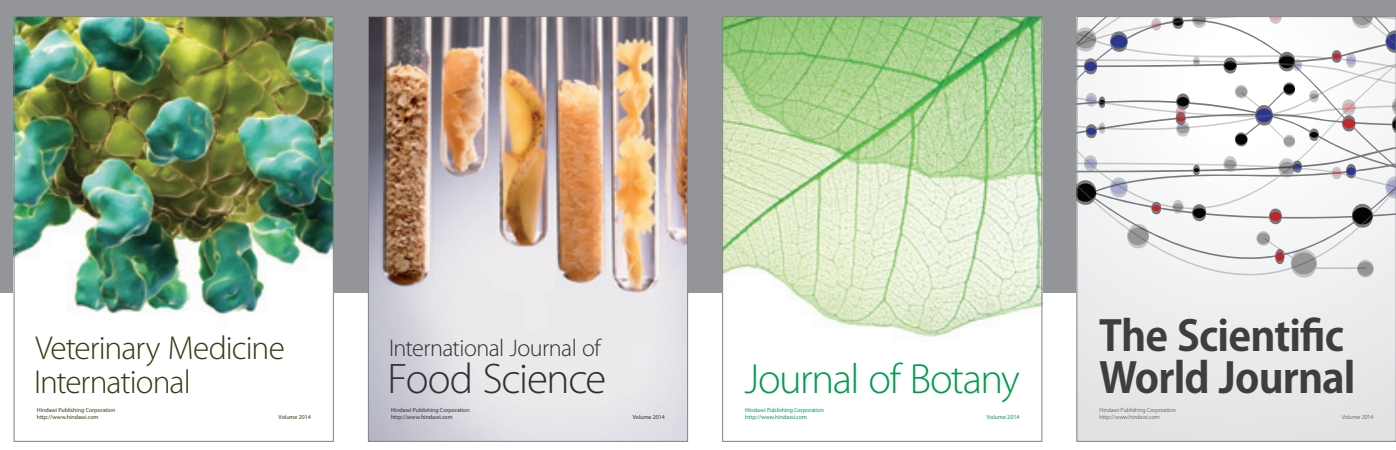

The Scientific World Journal
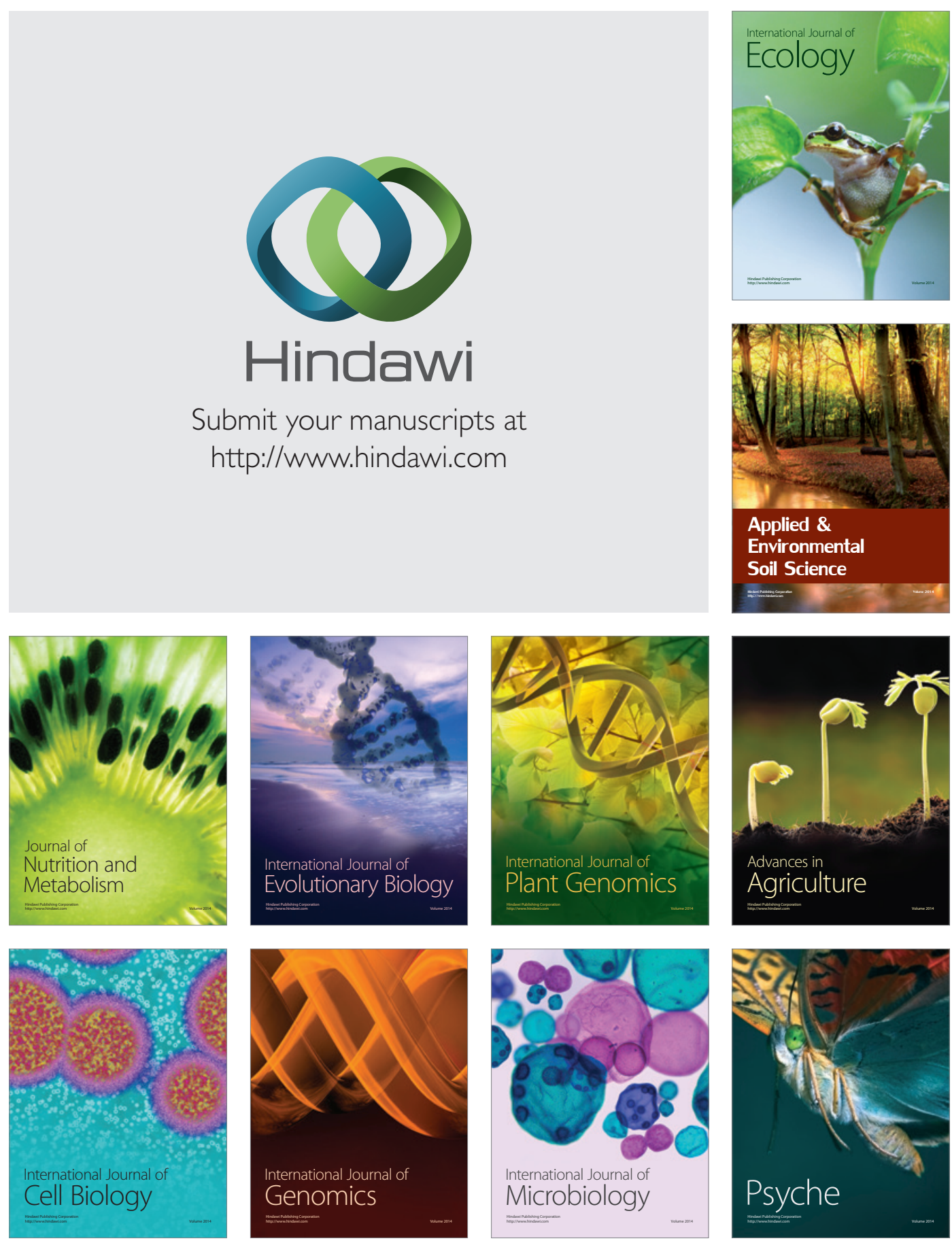